\title{
Laboratory colonization of Anopheles sinensis (Wiedemann, 1828)
}

\author{
Yuzuru OGUMA* and Tozo KANDA* \\ Department of Medical Zoology, School of Medicine St. Marianna University, \\ Sugao, Karcasaki 213
}

(Received: June 9, 1976 )

\begin{abstract}
After a strain of A. sinensis from Kanoya, Kyushu (Japan) was established by induced copulation with a human blood source for its first 26 generations, it has been further colonized for 19 generations in a small cage $(30 \times 30 \times 30 \mathrm{~cm})$ by free mating at $25 \pm 1{ }^{\circ} \mathrm{C}, 70-80 \% \mathrm{R}$. H. Larval stages were mass reared on the pulverized food consistng of equal weights of wheat germ, dry yeast and oatmeal. The mating ability of males during induced copulation was investigated; 3 day-old males were completely successful at mating but the quantity of sperm in the spermathecae was very low. The insemination rates were about $16 \%$ in the 31 st generation, $41 \%$ in the 41 st generation. A. lesteri has also been maintained mainly with a mouse blood source in a small cage for 15 generations without induced copulation. The insemination rate of this species was about $8 \%$ at the 11 th generation. The tolerance of the eggs of $A$. sinensis to desiccation was tested and it was found that the eggs hatched normally after 2 days of desiccation but the hatchability decreased down to $29 \%$ after 4 days.
\end{abstract}

Anopheles (A.) sinensis is a member of the A. hyrcanus species group, and is found in northeastern India, Malaysia, Thailand, Vietnam, Indonesia, Korea, China, Japan and eastern Siberia. It is the important vector of Brugia malayi (Filariae) in China (Feng, 1931). Recently, Kanda et al. (1975) have found that $A$. sinensis is one of important vectors of Brugia malayi in the inland areas of the Korean peninsula. From these facts $A$. sinensis can be regarded as a species of considerable medical importance. However, Harrison (1973) studied the identities of the "sinensis" found naturally infected with filarial and malarial parasites and suggested that the vector role of $A$. sinensis is decreasing.

In Japan, A. sinensis is the most widely distributed and common species of anopheline mosquitoes. It may be reared only with

This study was supported by the grant from the Ministry of Education, the Government of Japan.

* 小熊 譲, 神田鍊藏：聖マリアンナ医科大学病害 動物（兵 213 神奈川県川㥓市菅生 2095） difficulty in the laboratory, and only a few studies have been made on the laboratory rearing of this species (Keegan et al., 1964 ; Tanaka and Hatoyama, 1967). They collected many larvae in the field at the start of colonization and obtained matings in a large cage and then gradually adapted the colony to smaller cages in the laboratory. They also changed rabbits to guinea pigs as a source of blood. However, their method is not directly applicable for our experiments because of the difficulties in obtaining enough mosquitoes in the field for colonization and in running the risk of contamination with sympatric species from the field. Therefore we tried to establish the laboratory colonies of $A$. sinensis by the induced copulation method according to Baker et al. (1962), for the purposes of genetic, biological and also epidemiological studies as the vectors of malaria and filariasis. After generations of the established colonies they have been selected to copulate naturally in cages and to take mouse blood instead of human blood. 
The purpose of this paper is to report the successful colonization by induced or natural copulation in small cages of an indigenous strain of $A$. sinensis in Japan.

\section{INDUCED COPULATION Methods}

\section{Materials and methods}

About 70 blood-fed females of A. sinensis were obtained for laboratory colonization by using an aspirator during the night or day in pigpens and cattle shed in breeding areas at Kanoya City, Kagoshima Prefecture in Kyushu, approximately $1,000 \mathrm{~km}$ southwest of Tokyo. Females were anesthetized with ether and more than half of each of the wings was cut off by a knife. Then about five females were put in each container $(6$ $\mathrm{cm}$ in diameter, $3 \mathrm{~cm}$ in depth) containing wet filter paper, and these containers were kept in a cool box (about $23^{\circ} \mathrm{C}$ ) and carried to our laboratory by train. The oviposition was already observed to have started in transit and back in the laboratory the eggs were transferred to a white pan $(40 \times 25 \times$ $6 \mathrm{~cm}$ in depth) made of polyvinyl and lined with filter paper. The eggs hatched well after 4 days. Pulverized food, consisting of equal weights of wheat germ, dry yeast, and oatmeal was sprinkled on the water surface in the rearing pan one or two times a day and the rearing water was not changed during larval development. The larvae were diluted serially during their growth to prevent overcrowding, and the larval density ranged from several thousand in the first instar stage to less than 500 per pan in fourth instar; pupae were gathered with a wide-mouthed pipette and transferred to small cups. After their emergence in a small cage $(20 \times 20 \times 20 \mathrm{~cm})$ the adult nutriment was furnished by cotton pads saturated with about $3 \%$ sugar solution. Three days and again 5 days after emergence human blood was given to female mosquitoes; each of the blood-fed females was artificially copulated with 3 day-old males. About 50 copulated females were kept in the small cage with $3 \%$ sugar solution until the wings of parous females were cut off to promote oviposition. The laboratory humidity could not be controlled for the first 7 generations but after the 8th generation mosquitoes were reared at a controlled temperature of $25 \pm 1^{\circ} \mathrm{C}$ with a controlled relative humidity of 70 $80 \%$. After 27 generations the Kanoya strain maintained by this induced copulation method copulated successfully even in the small cages and took blood meals from mice.

\section{Experimental results}

Table 1 shows the number of oviposited eggs, their hatchability, the viability of the larvae in 8 th and 19 th generations of the Kanoya strain, and also in the 6 th generation of the Yakumo strain. The latter strain was collected to establish another colony at Yakumo, Hokkaido. It took 2 days from oviposition to hatching, and at least another 8 days to appearance of the first pupae, but additional 2 weeks or more were required for the pupation of all larvae. The males of the 19 th generation of the Kanoya strain were tested for their mating ability by induced copulation, using 20 individuals of each age from 1 through 6 days. The results are shown in Table 2 . The 3 day-old males had completely successful mating at the highest mating rate, but in order to confirm an ejaculation into the females artificially mated with the 3 day-old males the spermathecae in the females were dissected to observe the quantity of sperm in them. In this experiment $80 \%$ of the

Table 1 Fecundity of $A$. sinensis after induced copulation

\begin{tabular}{lccccc}
\hline $\begin{array}{l}\text { Strains and } \\
\text { generation }\end{array}$ & $\begin{array}{l}\text { No. of } \\
\text { females } \\
\text { tested }\end{array}$ & $\begin{array}{l}\text { Total no. } \\
\text { of eggs } \\
\text { oviposited }\end{array}$ & $\begin{array}{l}\text { Mean no. } \\
\text { of eggs/ } \text { ov }_{1} \\
\text { oviposited }\end{array}$ & $\begin{array}{l}\text { Hatch- } \\
\text { ability } \\
(\%)\end{array}$ & $\begin{array}{l}\text { Viability }(\%) \\
\text { from 1st to } \\
\text { 4th instar }\end{array}$ \\
\hline Kanoya $F_{8}$ & 4 & 940 & 235.0 & 31.4 & - \\
Kanoya $F_{19}$ & 6 & 1,676 & 279.3 & 22.4 & 78.0 \\
Yakumo $F_{6}$ & 5 & 1,645 & 329.0 & 18.0 & 68.0 \\
\hline
\end{tabular}


Table 2 The mating ability of males used in induced copulation

\begin{tabular}{cccc}
\hline $\begin{array}{c}\text { Days after } \\
\text { emergence }\end{array}$ & $\begin{array}{c}\text { No. of males } \\
\text { tested }\end{array}$ & $\begin{array}{c}\text { No. of males } \\
\text { which copulated }\end{array}$ & $\begin{array}{c}\text { ó of males } \\
\text { which copulated }\end{array}$ \\
\hline 1 & 20 & 2 & 10 \\
2 & 20 & 17 & 85 \\
3 & 20 & 20 & 100 \\
5 & 20 & 19 & 95 \\
6 & 20 & 14 & 70 \\
\hline
\end{tabular}

spermathecae dissected contained very few sperm, no sperm being in $20 \%$ of the spermathecae. It is, therefore, considered that the quantity of the sperm ejaculated by only one male at the induced copulation was not sufficient for one female to lay eggs.

\section{Natural Copulation with Utiliza- tion of Mice as a BloOd Source}

\section{Materials and methods}

In order to establish a colony capable of freely mating in a cage without induced copulation (after the 27 th generation of the Kanoya strain), the following experiment was done: a total of about 1,000 newly emerged females and males were gathered in a cage $(30 \times 30 \times 30 \mathrm{~cm})$ for a week and a mouse restrained with screen mesh was exposed in the cage every night during a 2 week period. An egg deposition cup with rearing water was provided in the cage.

The insemination rates were tested in the 31 st and the 41 st generations of the Kanoya strain of $A$. sinensis using two kinds of the small cages $(20 \times 20 \times 20 \mathrm{~cm}$ and $30 \times 30 \times 30$ $\mathrm{cm})$. About 500 newly emerged adults had been gathered in smaller cage and 1,000 adults into the other cage, during one week, then after five days $20 \%$ of the females were sampled from each cage to be dissected. A. lesteri was also tested at its 8 th generation using a $30 \times 30 \times 30 \mathrm{~cm}$ cage.

In order to examine tolerance of the eggs to desiccation, eggs deposited within 12 hours were completely desiccated on filter paper and then their hatchability was checked. For the comparison, hatchability of the eggs which were kept at $90 \%$ relative humidity was observed. Two hundred eggs were tested a day.

\section{Experimental results}

The insemination rates are shown in Table 3. Only slight differences between the rates obtained in the two kinds of small cages of the same generation of $A$. sinensis were found, but the insemination rates of A. sinensis were raised by about $20 \%$ in each small cage between the 31 st and the 41 st generations.

Blood-fed females began to deposit eggs two days after each blood meal, and repeated

Table 3 Insemination rates using by natural copulation in Anopheles sinensis and A. lesteri

\begin{tabular}{|c|c|c|c|c|c|}
\hline $\begin{array}{l}\text { Species and } \\
\text { generation }\end{array}$ & $\begin{array}{l}\text { Cage* } \\
\text { used }\end{array}$ & $\begin{array}{l}\text { No. of } \\
\text { females }\end{array}$ & $\begin{array}{l}\text { No. of } \\
\text { males }\end{array}$ & $\begin{array}{l}\text { No. of females } \\
\text { dissected }\end{array}$ & $\begin{array}{l}\text { Insemination } \\
\text { rate }(\%)\end{array}$ \\
\hline \multirow{3}{*}{$\begin{array}{l}\text { A. sinensis } \\
\text { Kanoya } \mathrm{F}_{31}\end{array}$} & A & 500 & 500 & 100 & 16 \\
\hline & $\mathrm{B}$ & 250 & 250 & 50 & 18 \\
\hline & $\mathrm{A}$ & 500 & 500 & 100 & 41 \\
\hline Kanoya $F_{41}$ & $\mathrm{~B}$ & 250 & 250 & 50 & 42 \\
\hline $\begin{array}{l}\text { A. lesteri } \\
\text { Yakumo } F_{8}\end{array}$ & A & 500 & 500 & 100 & 8 \\
\hline
\end{tabular}

* A : $30 \times 30 \times 30 \mathrm{~cm}$ cage

B : $20 \times 20 \times 20 \mathrm{~cm}$ cage 
their oviposition several times. The numbers of eggs laid the second and third times were greater than the first time, and decreased afterwards; the number of the eggs deposited at the second time in case of a $30 \times$ $30 \times 30 \mathrm{~cm}$ cage was about 10,000 to 15,000 and hatchability was $92 \%$ in the 41 st generation.

The results of tolerance of the eggs to desiccation are shown in Fig. 1. It was

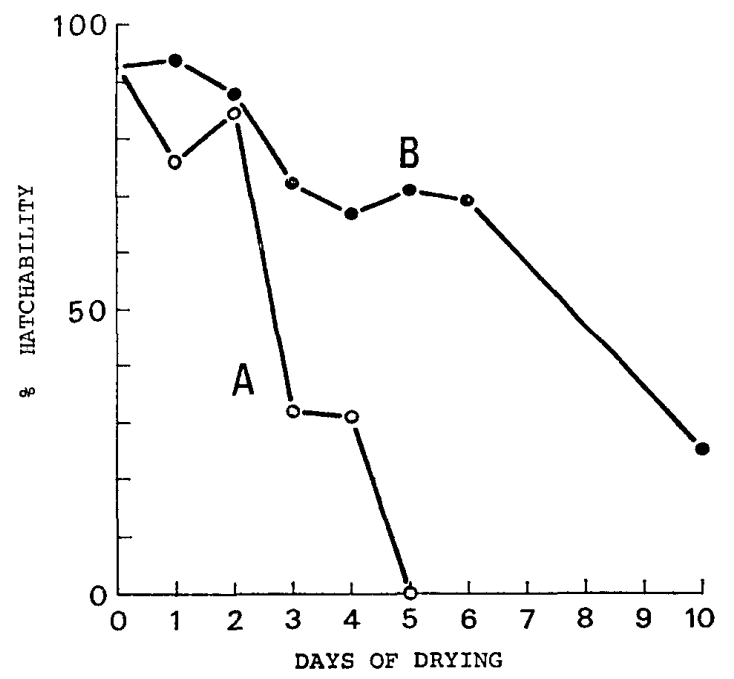

Fig. 1 Results of tolerance of eggs to desiccation using Anopheles sinensis Kanoya $\mathrm{F}_{42}$

A : Eggs desiccated completely. B : Eggs kept at $90 \%$ relative humidity.

found that the eggs hatched normally after 2 days of desiccation but the hatchability decreased down to $29 \%$ after 4 days with no hatch occurring beyond 5 days. On the other hand, $70 \%$ of the eggs kept at $90 \%$ relative humidity for 6 days hatched and a hatchability of $23.5 \%$ was observed even after 10 days.

\section{Discussion}

Difficulties in colonization of $A$. sinensis in the laboratory might be due to at least two factors; one was that adults were not capable of copulation in the small cage and the other was that they died easily in low humidity. It was very difficult to maintain the strain by induced copulation in our laboratory in the early generations, especially in winter because the humidity was not controlled, but the adult mortality decreased after the humidity could be controlled.
A cooler box was very useful for transportation of the female mosquitoes to the laboratory, especially from a long distance since the lower temperature prevented the hatch or development of eggs deposited by some blood-fed females. It was possible to carry alive adults without many deaths in a paper box in which sufficient humidity was maintained; but during transportation of the mosquitoes in this way for more than 3 days they require another blood meal in transit.

Tap water was used at first for larval rearing, but thereafter we switched to deionized water for the sake of safety. Rearing water was not changed in most of the pans during larval development. Finely ground mouse pellets gave good results for larval growth as did oatmeal; the males which emerged from good larval rearing conditions were capable of being used for induced copulation for more days; almost all the males of this kind, even up to 10 days old, were able to be utilized for induced copulation. On the contrary, the males produced by insufficient rearing condition such as undernourishment or overcrowding could mate only for a limited time or even could'nt.

Hatchability of the eggs obtained from the hand-copulated females was very different from the naturally inseminated females; the former was $20 \%$ and the latter $92 \%$. Judging from observation of the sperm in the spermathecae ejaculated by the induced copulation, the males appeared to have accomplished incomplete insemination ; therefore, after the 21 st generation of the Kanoya strain, two or more males were used for copulation for each of the females of this strain; the hatchability increased to about $50 \%$. On the other hand most of the spermathecae of the freely mated females in the cage in the 41 st generation of the Kanoya strain were filled with sperm and not a case was found in which an insufficient amount of sperm was in the spermathecae, although the insemination rate was about $40 \%$. From this fact it seems that by natural copulation in the cages spermatheca could be filled with many sperm not by multiple mating, but by only one mating. 
However, in the 31 st generation of the same strain only a few of the freely mated females had the spermathecae filled with sperm and there were lesser amounts of the sperm in the spermathecae in the other females as compared with those of the 41 st generation. It seems, therefore, that the amounts of the sperm ejaculated by one free copulation increased along with the rise in the insemination rate in the cage.

Tanaka and Hatoyama (1967) colonized this species in a large cage $(90 \times 72 \times 90 \mathrm{~cm})$; and after selection of eggs from the cage they finally could maintain this strain in a small cage $(45 \times 45 \times 45 \mathrm{~cm})$; a hatchability of $66 \%$ to $72 \%$ could be obtained in this small cage. This hatchability appeared to be due to the high mating rate of the strain. They initially used a rabbit as a source of blood and although the biting rate was low at first it gradually increased in subsequent generations. In the 8 th generation this colony was able to take blood from guinea pigs although it refused this blood source in its first generation. Our strain showed an insemination rate of $16 \%$ at the first time after released into a small cage $(30 \times 30 \times 30$ $\mathrm{cm}$ ) for free copulation and then the rate increased by more than $20 \%$ after ten generations. It is not reasonable to compare our data with those of Tanaka and Hatoyama (1967), since the strain used in our experiment had been maintained by induced copulation for the first 28 generations. Our strain refused guinea pig, pigeon or mouse as a blood source in its early generations; the strain also needed a long period of time even for taking human blood until the 20th generation; in the 27 th generation it showed a blood sucking rate of about $60 \%$ for mice, and therefore mice have been utilized for blood sources. Finally, nearly $90 \%$ of the mosquitoes took blood from mice at the 35 th generation. At present about 200 pupae per day are collected for one week and a mouse is supplied overnight for the adults every second day after the 10th day in the cages. Oviposition is observed 2 days after the blood meal.

The experiments of Tanaka and Hatoyama (1967) and those of the present authors suggest that after the biting rate in the early generations reaches to a certain level with the animal which the mosquitoes prefer as a source of blood, we may change the animal to another which is perhaps more handy but which the mosquitoes do not prefer originally as a blood source. As a matter of fact human blood probably could have been replaced by mouse blood in the earlier generations of our strain sooner that it actually was.

A. sineroides and A. koreicus were maintained by induced copulation for several generations but eventually were discontinued since to maintain many species of anopheline mosquitoes requires much labor. When colonization of the mosquitoes has to be started from a very few individuals, which perhaps must be collected at a distant locality, the induced copulation method is a good and effective technique for increasing the numbers of individuals, since an increase in numbers is essential for a freely mating strain of anopheline mosquitoes in a small cage. There are, of course, several species of anopheline mosquitoes including A. nigerrimus and A. pseudopictus which can copulate in small cages with few individuals even in the initial generations without need of induced copulation.

The Yakumo strain of A. lesteri being maintained in our laboratory bites man or mice more readily than does $A$. sincnsis. After the Yakumo strain was maintained by induced copulation for the first 6 generation, it has copulated freely in a $30 \times 30 \times 30$ $\mathrm{cm}$ cage, showing an insemination rate of $8 \%$ in 11 th generation. This strain is now in its 15 th generation, naturally copulates, and feeds freely on man or mouse.

\section{ACKNOWLEDGEMENTS}

We wish to express our thanks to Dr. M. Sasa, National Institute for Environmental Studies, Emeritus Prof. D. Moriwaki, Profs. S. Ohba and O. Kitagawa, Tokyo Metroporitan University, Dr. T. Tadano, St. Marianna University School of Medicine, and Dr. A. Shirasaka, Institute of Medical Science, University of Tokyo, for suggesting this investigation as well as for constant guidance in the course of the work. Thanks are also due to Emeritus Prof. J. B. Kitzmiller, University of Illinois, for his constructive sug- 
gestions and reading manuscript. Much valuable assistance in the laboratory was given by $\mathrm{Mr}$. S. Shinohara, Koumi Junior High School, Nagano Pref., and Misses K. Kuramochi and S. Yamasawa of the Department.

\section{REFERENCES}

Baker, R. H., W. L. French and J. B. Kitzmiller (1962) : Induced copulation in Anopheles mosquitoes. Mosquito News, 22 : 16-17.

Feng, L. C. (1931): Anopheles hyrcanus var. sinensis Wied., transmitter of Wuchereria (Filaria) bancrofti in Woosung district, Shanghai, China. Am. J. Hyg., 14 : 502-514.

Harrison, B. A. (1973): A lectotype designation and description for Anopheles (An.) sinensis Wiedemann 1828, with a discussion of the classification and vector status of this and some other oriental Anopheles. Mosqutio Systematics, 5 : 1-13.

Kanda, T., D. W. Choi and C. Y. Joo (1975) : Epidemiological studies on Malayan filariasis in an inland area in Kyungpook, Korea. Jap. J. Parasit., 24 : 177-183.

Keegan, H. L., H. Hatoyama, S. Toshioka and R. E. Weaver (1964): Note of a laboratory colony of the mosquito Anopheles (Anopheles) sinensis Wiedemann, 1828. Jap. J. Sanit. Zool.,
15 : 136-137.

Tanaka, K. and H. Hatoyama (1967) : On a few problems of ecology and rearing condition of laboratory colony of Anopheles sinensis. Jap. J. Sanit. Zool., 18 : 163 (in Japanese).

\section{摘 要 \\ Anopheles sinensis の実験室内飼育}

1970 年 7 月鹿児島県鹿屋市の豚舎, 牛舎内にて吸血 蚊を採集した。この吸血蚊の翅を半分以上ナイフで切断 し，湿った滤紙をしいた密閉容器 (径 $6 \mathrm{~cm}$, 媣さ $3 \mathrm{~cm}$ ) に 5 〜 6 頭ずつ移した. 3 日後に産卵が見られ，卵を白 色ポリビニール樹脂バット $(40 \times 25 \times 6 \mathrm{~cm})$ 一移した. この際バットの内側に幅約 $4 \mathrm{~cm}$ の濾紙をはりつけて おいた. 水は脱イオン水を使用した. 幼虫には微粉にし たドライ・イースト，小麦胚芽，オートミールを等量混 合した餌を若令期には 1 日 1 回，3〜4令期には 2 回水 面に浮くように与えた. 羽化後 3 日目の雌を人の手から 吸血させ，雄と強制交尾を行ない次代の卯学得た。実験 室は $25 \pm 1^{\circ} \mathrm{C}, 70 \sim 80 \%$ 湿度である.この方法で 27 代ま で飼育され，その後ケージ内での自然交尾，マウス吸血 への移行を試みたところ成功した. 雄の交尾能力は羽化 後 3 日目が最高であった. 卵の耐乾燥性について調査し たところ，孵化率は2 日目までは正常であったが，4日 後には $29 \%$ に減少した。 